\title{
Expression of Inflammatory Cytokines and Inducible Nitric Oxide Synthase in Brains of SIV-Infected Rhesus Monkeys: Applications to HIV-Induced Central Nervous System Disease
}

\author{
Thomas E. Lane, Michael J. Buchmeier, Debbie D. Watry, \\ and Howard S. Fox \\ Department of Neuropharmacology, The Scripps Research Institute, \\ La Jolla, California, U.S.A.
}

\begin{abstract}
Background: Human immunodeficiency virus type 1 (HIV-1) infection of the central nervous system (CNS) can lead to severe impairments in cognition, behavior, and motor skills. The mechanism(s) by which HIV-1 induces CNS disease are not well understood. Recent evidence suggests that expression of inducible nitric oxide synthase (iNOS) and nitric oxide (NO) may contribute to HIV-1-induced neurologic disease. We sought to determine if these factors were present in the CNS of rhesus monkeys with simian immunodeficiency virus (SIV)-induced CNS disease.

Materials and Methods: Total NO production in cerebral spinal fluid (CSF) from infected monkeys was determined by measuring nitrite $\left(\mathrm{NO}_{2}{ }^{-}\right)$and nitrate $\left(\mathrm{NO}_{3}{ }^{-}\right)$(stable $\mathrm{NO}$ degradation products) utilizing Greiss reagents. In situ hybridization revealed iNOS, interferon- $\gamma(\operatorname{IFN} \gamma)$, and interleukin $1 \beta(\mathbb{L}-1 \beta)$ mRNA in the
\end{abstract}

brains of SIV-infected monkeys. Microglia were isolated from animals infected with SIV. Following stimulation with LPS, induction of iNOS mRNA in isolated microglia was analyzed by reverse transcriptase-polymerase chain reaction.

Results: Serial CSF samples from an SIV-infected monkey reveal increased levels of $\mathrm{NO}_{2}{ }^{-} / \mathrm{NO}_{3}{ }^{-}$. In situ hybridization demonstrated iNOS, IFN $\gamma$, and IL- $1 \beta$ mRNAs in post-mortem brain tissue of SIV-infected monkeys. Furthermore, stimulated microglia from an SIV-infected monkey could produce iNOS mRNA.

Conclusions: The presence of iNOS in the brain and $\mathrm{NO}_{2}{ }^{-} / \mathrm{NO}_{3}{ }^{-}$in the $\mathrm{CSF}$ indicates that $\mathrm{NO}$ is produced in the CNS of SIV-infected monkeys. The data suggest that iNOS and NO may be contributing to SIV-induced CNS disease.

\section{INTRODUCTION}

Infection with human immunodeficiency virus type 1 (HIV-1) often leads to neurological disease (1-3). Disease can occur in the absence of opportunistic infection, suggesting that the virus itself and/or host response is the causative agent

Address correspondence and reprint requests to: Howard S. Fox, The Scripps Research Institute, $10666 \mathrm{~N}$. Torrey Pines Road, CVN 8, La Jolla, CA 92037, U.S.A.
(1-3). Clinical manifestations of HIV infection of the central nervous system (CNS) include deficits in cognition, behavior, and movement which collectively are referred to as the HIV-associated cognitive/motor complex; approximately $20-30 \%$ of acquired immunodeficiency syndrome (AIDS) patients develop a severe form of cognitive disorder which is also known as the AIDS dementia complex (ADC) (1-3). Although HIV encephalitis is frequently associated with $A D C$, there is no 
clear correlation between the development of ADC or any other neurological impairment and the severity of neuropathology (1-3). Moreover, while viral infection of the brain occurs, there is no clear link between viral load in the brain and neuropathology (1-3). Thus, the etiology of HIVassociated CNS disease remains a complex issue about which very little is understood. The development of a relevant animal model is imperative in order to better understand the pathobiology of HIV-induced CNS disease.

Simian immunodeficiency virus (SIV) is a nonhuman primate lentivirus that is genetically and biologically similar to HIV (for review, see Ref. 4). Both HIV and SIV display a tropism for $\mathrm{CD} 4{ }^{+}$lymphocytes and cells of the monocyte/ macrophage lineage (4). Experimental infection of SIV into rhesus monkeys results in an acquired immunodeficiency syndrome that closely parallels AIDS in HIV-1-infected humans (5). Lymphadenopathy, opportunistic infections, and a wasting disease are common clinical characteristics of SIV-infected rhesus monkeys and HIV1 -infected humans $(4,5)$. Furthermore, monkeys infected with SIV can develop CNS disease similar to HIV-1-associated neurologic disease in humans $(6,7)$. Currently, the SIV/rhesus monkey model represents one of the best animal models available in which to study CNS disease in HIV1-infected humans $(4,8)$.

We are interested in defining factors that contribute to CNS disease in monkeys experimentally infected with SIV. Within the brain, HIV and SIV predominantly infect macrophage and microglia (9-13). Recent studies indicate that virally infected cells release a variety of factors including viral products such as gp120 $(14,15)$, and host factors such as cytokines (1618), arachidonic acid metabolites (16), and quinolinic acid $(19,20)$ that could contribute to CNS disease. Another factor that is a potent neurotoxin is nitric oxide (NO), a short-lived radical generated through the action of nitric oxide synthase (NOS) which converts L-arginine to L-citrulline $(15,21-23)$. In vivo and in vitro, NO decomposes to the stable products nitrite $\left(\mathrm{NO}_{2}{ }^{-}\right)$ and nitrate $\left(\mathrm{NO}_{3}{ }^{-}\right)(21)$. Due to the short halflife of $\mathrm{NO}$ (on the order of seconds), $\mathrm{NO}_{2}{ }^{-}$and $\mathrm{NO}_{3}{ }^{-}$are often measured as an index for total NO production (21). Three isoforms of NOS have been identified in humans. Both neuronal constitutive NOS (ncNOS type I) and endothelial constitutive NOS (ecNOS type III) require calcium and calmodulin for activity (22). These enzymes consitutively produce low levels of NO that regulate everyday processes such as blood pressure, peristalsis, and neurotransmission (22).

The inducible form of NOS (iNOS type II) does not require calcium for activity (22). A variety of human cell types such as monocyte/ macrophage, astrocytes, and hepatocytes express iNOS. Transcription for this gene can be experimentally initiated following treatment with lipopolysaccharide (LPS) and cytokines such as interferon- $\gamma$ (IFN $\gamma$ ), tumor necrosis factor $\alpha$ $(\mathrm{TNF} \alpha)$, and interleukin $1 \beta$ (IL-1 $\beta$ ). iNOS activity produces high levels of NO thought to be important for host defense against tumor cells and wide variety of infectious agents including bacteria, fungi, and viruses (24). Conversely, high levels of NO can result in cell death and tissue destruction $(22,24)$. Potential sites of action of NO on target cells include inhibition of enzymes containing Fe-S groups (25), disruption of signal transduction (22), and induction of apoptosis (26). One other potential toxic property of NO is its ability to react with superoxide anion $\left(\mathrm{O}_{2}{ }^{-}\right)$to form peroxynitrite, which is directly cytotoxic to cells by causing lipid peroxidation and protein tyrosine nitration $(27,28)$.

Recently, attention has been drawn to the role of iNOS and NO as contributing factors in a variety of human CNS diseases, including HIV1-associated neurologic disease (29-31). In this study, we demonstrate that increased levels of $\mathrm{NO}_{2}{ }^{-} / \mathrm{NO}_{3}{ }^{-}$are present in the cerebrospinal fluid (CSF) of SIV-infected animals. Furthermore, we have shown that iNOS mRNA, as well as mRNA for the cytokines IFN $\gamma$ and IL- $1 \beta$, are expressed in the brains of SIV-infected monkeys. In addition, we report that microglia, target cells for SIV infection of the brain, can express iNOS mRNA when stimulated with LPS. The presence of these potentially neurotoxic products in the brains of SIV-infected monkeys may provide new insights into mechanisms by which SIVinduced CNS disease occurs.

\section{MATERIALS AND METHODS}

\section{Virus}

Rhesus peripheral blood mononuclear cells (PBMC)-amplified SIVmac251 stock virus, originally provided by R. Desrosier, New England Primate Research Center, Harvard University, and a previously described microglial-associated SIV stock (32) were used for experimental infection of rhesus monkeys. 


\begin{abstract}
Animals
Rhesus monkeys, free of type $D$ simian retroviruses and herpes $B$ virus, were obtained from an isolated colony on Key Lois Island, FL, U.S.A. (Charles River) and housed in an appropriate containment facility. Animals were handled only after being sedated by an intramuscular injection of ketamine-HCL.
\end{abstract}

\section{Experimental Infection of Rhesus Monkeys}

Monkey 185 was infected intravenously via the saphenous vein with the previously described microglial-associated SIV stock of virus (32), while monkey 262 was infected with a separate microglial-associated SIV stock. Monkey 188 was infected intravenously with the uncloned SIVmac251 stock of virus. All animals were monitored for the development of AIDS-associated illness at which time they were sacrificed. Histopathological examination of the brains of monkeys 185 and 188 revealed neuropathology characteristic of SIV encephalitis, whereas monkey 262 had scattered macrophages and T cells in the brain. SIV sequences could be polymerase chain reaction-amplified from DNA prepared from microglia purified from these animals.

\section{Cell Culture}

Monkeys were euthanized by lethal anesthesia, followed by intracardial perfusion with sterile phosphate-buffered saline (PBS). Microglia were obtained according to previously described methods (32). A total of five million cells were seeded into $15 \times 60 \mathrm{~mm}$ culture dishes in a volume of $2 \mathrm{ml}$. Cells were cultured in macrophage-serum free medium (M-SFM) (Gibco/ BRL, Grand Island, NY, U.S.A.) supplemented with $10 \%$ Mac-Stim (MS) solution (Collaborative Biomedical Products, Bedford, MA, U.S.A.), which is enriched with macrophage colonystimulating factor and granulocyte/macrophage colony-stimulating factor, for 5 days in a humidified $37^{\circ} \mathrm{C}, 6 \% \mathrm{CO}_{2}$ cell incubator. At the completion of the incubation period, the cells were gently washed with pre-warmed $\left(37^{\circ} \mathrm{C}\right)$ Hanks' balanced salt solution (HBSS) to remove nonadherent cells. This resulted in a confluent monolayer of cells, of which $>95 \%$ were microglia, as determined by uptake of fluorescently labeled acetylated low-density lipoprotein (Dil-Ac-LDL) (Biomedical Technologies Inc., Stoughton, MA,
U.S.A.) (32). Fresh medium was added to the monolayers every 3 days.

\section{CSF $\mathrm{NO}_{2}{ }^{-} / \mathrm{NO}_{3}{ }^{-}$Measurement}

Serial CSF samples were collected from SIV-infected monkeys (185 and 262) by tapping the cisterna magna. Only blood-free CSF were used for $\mathrm{NO}_{2}{ }^{-} / \mathrm{NO}_{3}{ }^{-}$analysis by the protocol from the Cayman Nitrite/Nirate Assay Kit (Alexis Corporation, San Diego, CA, U.S.A.). Briefly, the reaction is a two-step process with the first step converting $\mathrm{NO}_{3}{ }^{-}$to $\mathrm{NO}_{2}{ }^{-}$using nitrate reductase and the second step utilizing the Griess reagents to chemically convert $\mathrm{NO}_{2}{ }^{-}$into an azo compound. Total $\mathrm{NO}_{2}{ }^{-} / \mathrm{NO}_{3}{ }^{-}$compounds are then determined by spectrophotometric absorbance at $540 \mathrm{~nm}$.

\section{p27 Antigen Measurement}

Plasma and CSF samples were collected from monkeys (185 and 262) and stored at $-70^{\circ} \mathrm{C}$ until analyzed. SIV p27 antigen was measured using a commercial SIV p27 antigen capture enzyme-linked immunosorbent assay (ELISA) kit according to manufacturers specifications (Coulter Corporation, Hialeah, FL, U.S.A.).

\section{Reverse Transcriptase-Polymerase Chain Reaction Analysis}

Microglia from monkey 262 were cultured with or without LPS (100 ng/ml) for $24 \mathrm{hr}$ at which time total cellular RNA was prepared by guanidinium thiocyanate/phenol/chloroform extraction (33). cDNA from each cell population was prepared with $1 \mu \mathrm{g}$ of RNA as template using Moloney murine leukemia virus reverse transcriptase (Promega, Madison, WI, U.S.A.) and random hexamer nucleotide primers (Promega) (33). Fifty microliters total volume of cDNA was prepared, of which $4 \mu \mathrm{l}$ was polymerase chain reaction (PCR) amplified in $50 \mu$ l reaction containing $1.5 \mathrm{mM} \mathrm{MgCl}_{2}, 0.2 \mathrm{mM}$ each of the four deoxynucleotide triphosphates, $0.5 \mathrm{U}$ of Taq polymerase, and $0.7 \mu \mathrm{M}$ each of primers specific for human iNOS and mouse L32. The iNOS primers correspond to nucleotides 212-232 (CTG TCC TTG GAA ATT TCT GTT) and 699-680 (TGG CCA GAT GTT CCT CTA TT) of the human hepatocyte iNOS. The mouse $\mathrm{L} 32$ primers were as follows: 5'-GTG GGG CCC AAG ATC GTC AAA AAG- $3^{\prime}$ and 5'-CAG TAC GTA AGA TT T GTT GCA CAT-3'. RNA from rhesus monkey micro- 
glia and PMA-stimulated PBMC was used to generate CDNA in order to PCR amplify IL- $1 \beta$ and IFN $\gamma$, respectively, by using primers based on the human cDNA sequences. Oligonucleotide primers for IL- $1 \beta$ amplification were purchased from Clonetech Laboratories (Palo Alto, CA, U.S.A.). Oligonucleotide primers for IFN $\gamma$ amplification were as follows: $5^{\prime}$-CTC GAA TTC TTA ATT CTC TCG GAA ACG ATG-3' and 5'-GTG GGA TCC TTG AAA CAG CAT CTG ACT CCT-3'. PCR amplification for all molecules was performed using an automated DNA thermocycler (MJ Minicycler) with the following profile: (Step 1) initial denaturation at $95^{\circ} \mathrm{C}$ for $2 \mathrm{~min}$, (Step 2) denaturation at $93^{\circ} \mathrm{C}$ for $20 \mathrm{sec}$, (Step 3) annealing at $55^{\circ} \mathrm{C}$ for $30 \mathrm{sec}$, (Step 4) extension at $72^{\circ} \mathrm{C}$ for 1 $\min 15 \mathrm{sec}$. Step 2 to Step 5 were repeated 38 times for a total of 39 cycles. A final extension at $75^{\circ} \mathrm{C}$ for $5 \mathrm{~min}$ was performed. The amplified products were analyzed on a $1.8 \%$ agarose gel containing $0.5 \mu \mathrm{g} / \mathrm{ml}$ ethidium bromide and extracted using the Gene Clean II system (Bio 101, Carlsbad, CA, U.S.A.) and cloned into the pCRScript SK (+) vector (Stratagene, San Diego, CA, U.S.A.). Double-stranded plasmid clones were sequenced by primer-directed dideoxy chain termination method with dye-labeled terminators using the Prism Terminator Kit (Applied Biosystems, Inc., Foster City, CA, U.S.A.) with DNA Sequencer Model 373A (Applied Biosystems). To eliminate PCR errors, the sequences of four individual clones were examined. iNOS nucleotide and predicted amino acid sequences were analyzed using the MacVector Sequence Analysis Program version 3.5 (Kodak Co., New Haven, CT, U.S.A.).

\section{Nucleotide Sequence Accession Number}

The concensus sequence for the iNOS clone described in this report has been filed with Genbank under Accession No. U31907.

\section{In Situ Hybridization}

In situ hybridization of brain sections was performed using fragments of the monkey cDNAs for iNOS, IL- $1 \beta$, and IFN $\gamma$ as a probe. Brain tissue was fixed in $10 \%$ formaldehyde for $48 \mathrm{hr}$, then suspended in $70 \%$ ethanol prior to processing in paraffin blocks. Six micron-thick sections of monkey brain were cut and floated onto Vectabond (Vector Laboratories, Burlingame, CA, U.S.A.) treated Superfrost slides (Fisher, Pittsburgh, PA, U.S.A.), dried overnight, and de- waxed. The slides were submerged in $50 \mu \mathrm{g} / \mathrm{ml}$ proteinase $\mathrm{K}$ (Fisher), in proteinase $\mathrm{K}$ buffer

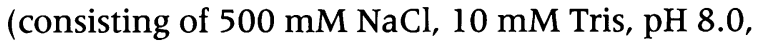
$5 \mathrm{mM}$ EDTA) for $20 \mathrm{~min}$, then washed twice in $0.5 \mathrm{X}$ SSC. The slides were prehybridized with $100 \mu \mathrm{l}$ of $2 \mathrm{X} \mathrm{SSC}, 50 \%$ formamide, $10 \%$ dextran sulfate, IX Denhardt's solution and incubated at $46^{\circ} \mathrm{C}$ for $1 \mathrm{hr} .{ }^{35} \mathrm{~S}$-labeled riboprobe $\left(3 \times 10^{6}\right.$ cpm) was added to the slides in a $50 \mu$ l volume and hybridized overnight at $46^{\circ} \mathrm{C}$. The slides were washed twice in 2X SSC-1 mM EDTA, then immersed in $20 \mu \mathrm{g} / \mathrm{ml}$ RNAse A in RNAse buffer ( $500 \mathrm{mM} \mathrm{NaCl}, 10 \mathrm{mM}$ Tris, $\mathrm{pH} \mathrm{8.0)}$ ) for $30 \mathrm{~min}$ at room temperature. The slides were then washed twice with $2 \mathrm{X} \mathrm{SSC}-1$ mM EDTA at room temperature; followed by two 1-hr incubations with $0.2 \mathrm{X} \mathrm{SSC}-1 \mathrm{mM}$ EDTA at $42^{\circ} \mathrm{C}$, then washed twice with $0.5 \mathrm{X}$ SSC at room temperature. The slides were dehydrated and dried. Slides were dipped in a Kodak/N2B2 nuclear emulsion at $42^{\circ} \mathrm{C}$ and exposed at $4^{\circ} \mathrm{C}$ for 2 -to-4 weeks in a desiccator. Slides were developed and fixed using Kodak D-19 developer and fixer, and counterstained with hematoxylin and eosin $\mathrm{Y}$ solutions, dehydrated, and mounted. Slides hybridized to control riboprobes remained negative.

\section{RESULTS}

\section{$\mathrm{NO}_{2}{ }^{-} / \mathrm{NO}_{3}{ }^{-}$Is Present in the CSF of SIV-Infected Monkeys}

Elevated levels of host factors such as cytokines, quinolinic acid, and other potential neurotoxins have been identified in the CSF of patients with HIV-1-associated neurologic disease (34-36). We examined CSF samples of monkeys experimentally infected with SIV for the presence of $\mathrm{NO}_{2}{ }^{-} / \mathrm{NO}_{3}{ }^{-}$as an indicator of NO production in the CNS of these animals. The data in Fig. 1A represent $\mathrm{CSF} \mathrm{NO}_{2}{ }^{-} / \mathrm{NO}_{3}{ }^{-}$values of one such monkey (185) who displayed SIV encephalitis at necropsy (32). $\mathrm{NO}_{2}{ }^{-} / \mathrm{NO}_{3}{ }^{-}$were not detected in the CSF prior to infection. However, 7 days after infection a sharp increase in $\mathrm{CSF} \mathrm{NO}_{2}{ }^{-} / \mathrm{NO}_{3}{ }^{-}$ levels occurred (up to $8 \mu \mathrm{M}$ ), which then decreased to undetectable levels by Day 65 postinfection. As the animal grew progressively ill, $\mathrm{NO}_{2}{ }^{-} / \mathrm{NO}_{3}{ }^{-}$levels increased until the maximum concentration $(10.7 \mu \mathrm{M})$ was recorded on the day of sacrifice. The increase in $\mathrm{NO}_{2}{ }^{-} / \mathrm{NO}_{3}{ }^{-}$in the CSF did not parallel the detection of viral antigen as only low levels of viral p27 antigen were detected in the CSF early in infection, 

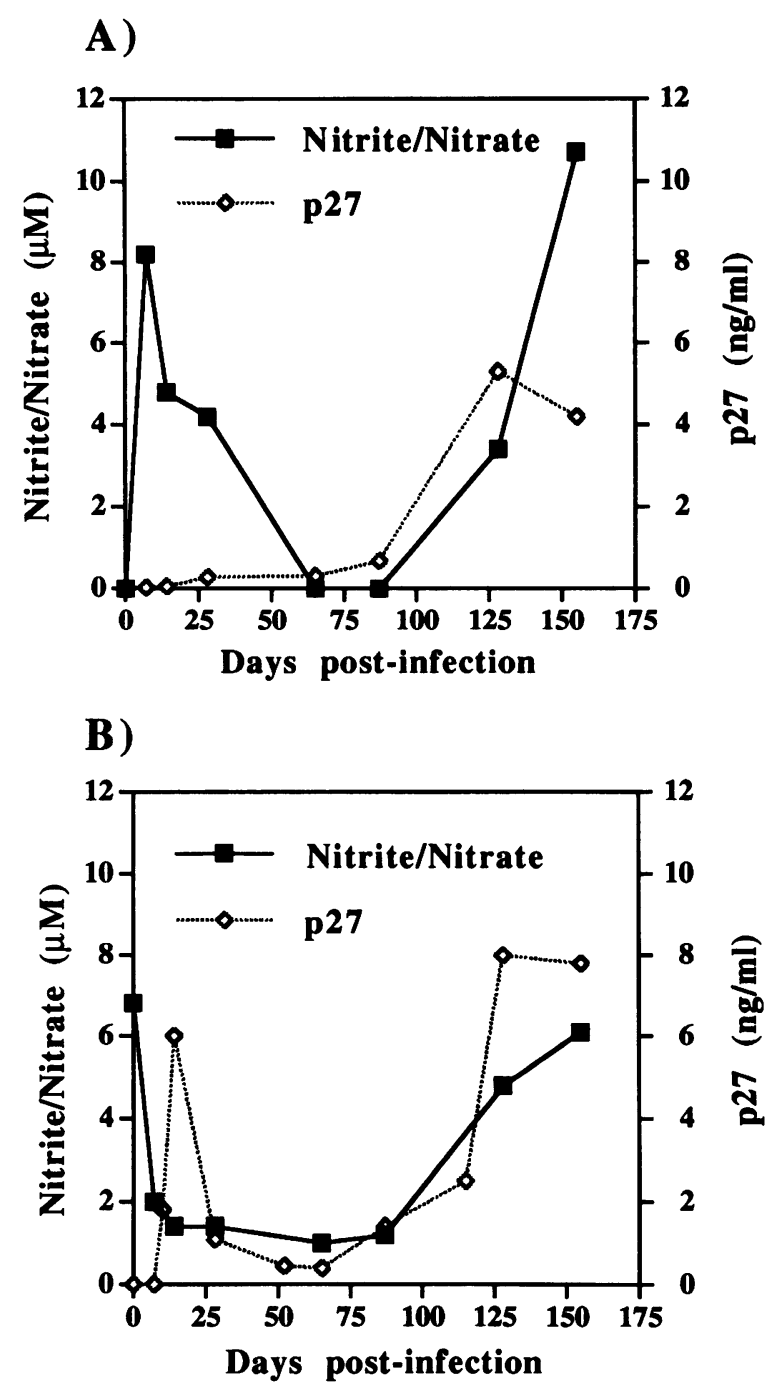

FIG. 1. Analysis of $\mathrm{NO}_{2}{ }^{-} / \mathrm{NO}_{3}{ }^{-}$and SIV p27 antigen levels in serial CSF and plasma samples following SIV infection

(A) CSF and (B) plasma samples were collected at Days $0,7,14,28,65,87,128$, and 155 postinfection from monkey 185 and $\mathrm{NO}_{2}{ }^{-} / \mathrm{NO}_{3}{ }^{-}$and p27 levels determined as described in Materials and Methods. Each point represents a single sample.

which increased as the animal became ill (Fig. 1A). Plasma $\mathrm{NO}_{2}{ }^{-} / \mathrm{NO}_{3}{ }^{-}$levels from this monkey were higher than $\mathrm{CSF} \mathrm{NO}_{2}{ }^{-} / \mathrm{NO}_{3}{ }^{-}$levels prior to infection (Fig. 1B). Plasma $\mathrm{NO}_{2}{ }^{-} /$ $\mathrm{NO}_{3}{ }^{-}$levels declined following infection and plateaued until the animal became ill, at which point $\mathrm{NO}_{2}{ }^{-} / \mathrm{NO}_{3}{ }^{-}$levels increased.

In contrast to the findings in the CSF, plasma viral p27 antigen from monkey 185 spiked at Day 14 postinfection, rapidly decreased, then gradually rose again during the course of infection (Fig. 1B). Serial $\mathrm{CSF} \mathrm{NO}_{2}{ }^{-} / \mathrm{NO}_{3}{ }^{-}$values were also recorded from monkey 262 who did not display the multinucleate giant cells and microglial nodules characteristic of SIV encephalitis upon sacrifice. Low levels of $\mathrm{NO}_{2}{ }^{-} / \mathrm{NO}_{3}{ }^{-}(0-1.7 \mu \mathrm{M})$ were observed throughout the course of infection until the terminal date, at which point $\mathrm{NO}_{2}{ }^{-} / \mathrm{NO}_{3}{ }^{-}$ levels were higher $(12.1 \mu \mathrm{M})$ than detected in the CSF of monkey 185 . It is possible that NO could be produced in the plasma and $\mathrm{NO}_{2}{ }^{-} / \mathrm{NO}_{3}{ }^{-}$could diffuse into the CSF; however, this is unlikely due to the difference in kinetics observed between CSF and plasma $\mathrm{NO}_{2}{ }^{-} / \mathrm{NO}_{3}{ }^{-}$production. Furthermore, $\mathrm{NO}_{2}{ }^{-} / \mathrm{NO}_{3}{ }^{-}$anions are not thought to pass freely through the blood-brain barrier (37). Finally, only CSF samples free of blood were used for $\mathrm{NO}_{2}{ }^{-}$/ $\mathrm{NO}_{3}{ }^{-}$measurement, so it is unlikely that contaminating NO-producing PBMC were present within the CSF. Thus, these data suggest that the presence of $\mathrm{NO}_{2}{ }^{-} / \mathrm{NO}_{3}{ }^{-}$in the CSF of these monkeys reflects local NO production within the CNS.

\section{Detection of iNOS, IFN $\gamma$, and IL-1 $\beta$ by in Situ Hybridization}

In situ hybridization was used to detect expression of iNOS mRNA in postmortem brain tissue from SIV-infected monkeys. mRNA for iNOS was found in the cerebral cortex of a monkey (188) with SIV-encephalitis as well as a monkey that did not display encephalitis at autopsy (monkey 262) (Fig. $2 \mathrm{~A}$ and B). Since IFN $\gamma$ and IL- $1 \beta$ may contribute to iNOS expression in vivo, we also examined tissue from the brain of monkey 188 for expression of these cytokines. Both IFN $\gamma$ and IL- $1 \beta$ mRNA were demonstrated by in situ hybridization to be present in the same brain tissue in which iNOS mRNA was identified (Fig. $2 \mathrm{C}$ and D).

\section{Expression of iNOS by Microglia}

Treatment of human cells with LPS and/or cytokines such as IFN $\gamma$ results in production of iNOS mRNA (38-41). Furthermore, human macrophages as well as rodent glia cells produce iNOS/NO in response to the HIV-1 env glycoprotein $(15,30,42)$. Microglia from an SIV-infected monkey (262) were examined for the ability to express iNOS mRNA. Expression of iNOS was analyzed following 24-hr exposure of microglia to LPS by reverse transcriptase-polymerase chain reaction (RT-PCR) analysis using human iNOS specific primers. The expected PCR product was 
FIG. 2. IFN $\gamma$, IL-1 $\beta$, and iNOS are detected by in situ hybridization in the brains of SIV-infected monkeys

In situ hybridization reveals iNOS mRNA positive cells both adjacent to inflammatory lesions ([A] monkey 188: original magnification $25 \times)$ and in uninflamed areas ([B] monkey 262: original magnification $40 \times$ ). Examination for expressed cytokines revealed positive cells for IFN $\gamma([\mathrm{C}]$ monkey 188: magnification $40 \times$ ) and IL- $1 \beta$ ([D] monkey 188: magnification $40 \times)$.
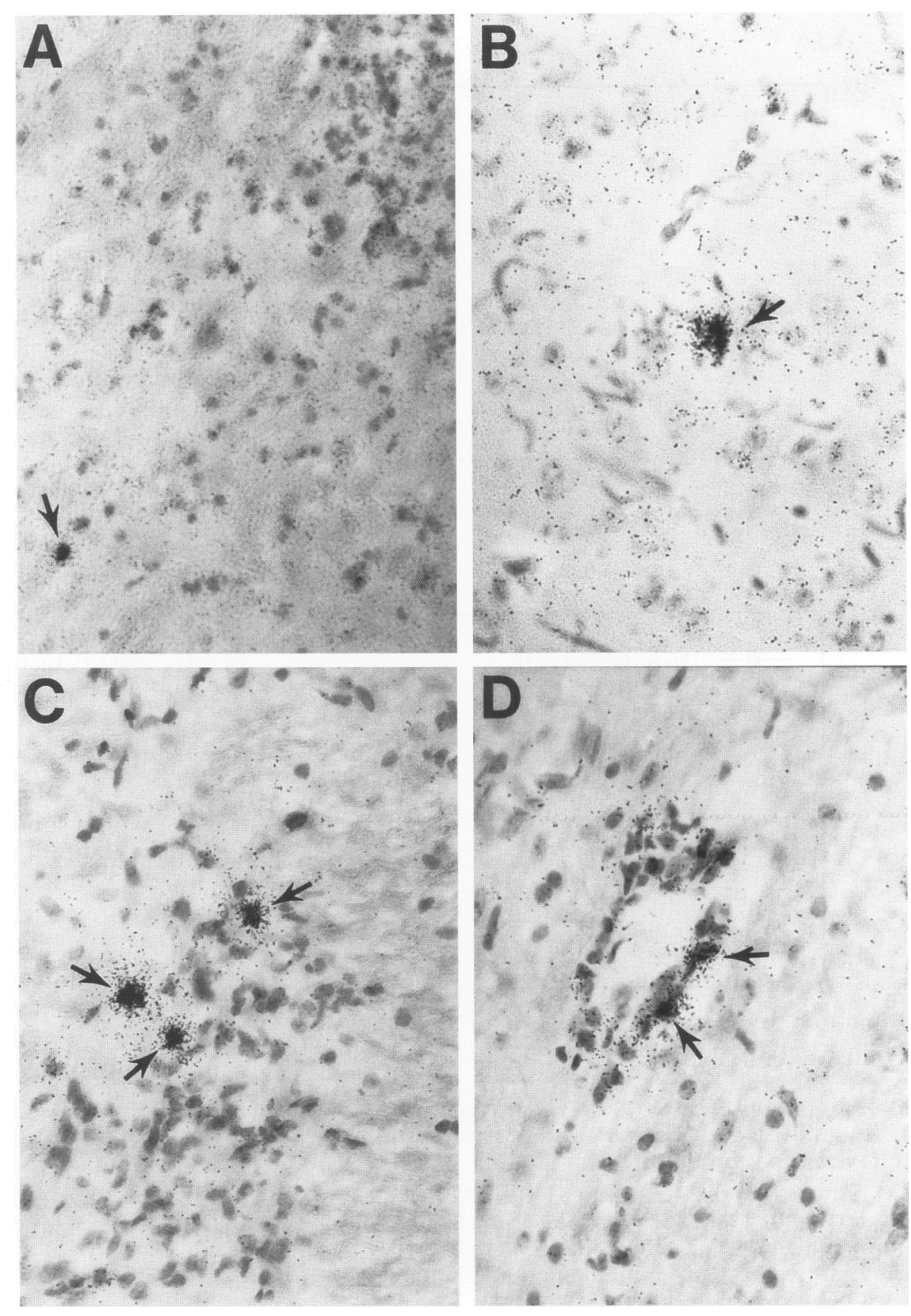

detected from LPS-treated microglia whereas no product was detected from untreated microglia (Fig. 3). Sequence analysis of the PCR product revealed greater than $95 \%$ nucleotide and amino acid similarity to human hepatic iNOS (Fig. 4). There was no significant similarity to human ncNOS or ecNOS. It is unlikely that contaminating PBMC were responsible for iNOS production as the brain was perfused extensively prior to isolation of microglia. These results demonstrate that SIV-infected microglia can produce iNOS mRNA following stimulation with LPS.

\section{DISCUSSION}

The production of NO by iNOS in the brain is thought to represent an important component of the host immune response as well as potentially contribute to neuropathology. Rodents infected 


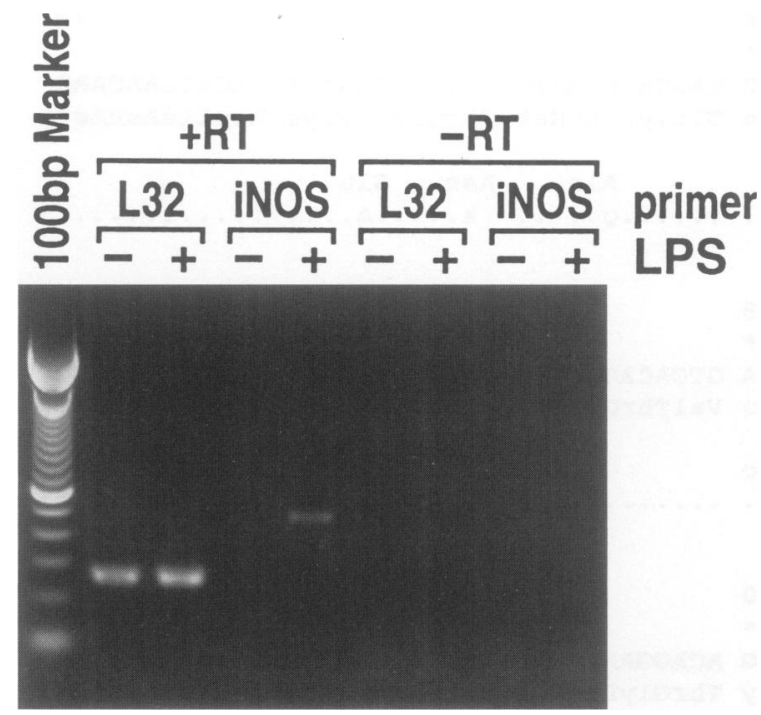

FIG. 3. Microglia obtained from an SIV-infected monkey produce iNOS following 24-hr LPS stimulation

cDNA was made from total cellular RNA isolated from microglia (monkey 262) stimulated with LPS $(+)$ or cultured in medium alone $(-)$. PCR was performed with primers specific for iNOS or L32. Samples to which reverse transcriptase was $(+\mathrm{RT})$ or was not $(-\mathrm{RT})$ added are indicated. The expected PCR product for iNOS was obtained in microglia treated with LPS. The expected size PCR products for L32 were obtained, and the data indicate that equal amounts of CDNA were used for the PCR reaction.

with lymphocytic choriomeningitis virus (LCMV) (43) and borna virus (44) expressed iNOS in the brain which coincided with the development of neuropathology. In humans, iNOS has been indirectly identified by NADPH diaphorase staining in regions of demylination in patients suffering from multiple sclerosis (MS), suggesting a role for NO in the pathogenesis of MS lesions (29). Recently, expression of iNOS has been speculated to have a role in HIV-1-induced neuropathology $(1,15,31)$. In support of this, iNOS mRNA has been detected by RT-PCR in postmortem brain tissue of a child with advanced HIV encephalitis (30). We have demonstrated that an increase in $\mathrm{NO}_{2}{ }^{-} / \mathrm{NO}_{3}{ }^{-}$levels is observed in the CSF of monkeys with SIV-induced CNS disease. iNOS, IFN $\gamma$, and IL- $1 \beta$ mRNA were all observed in the brains of SIV-infected monkeys by in situ hybridization. Furthermore, LPS-stimulated microglia from an SIV-infected monkey produce iNOS mRNA. These data suggest that iNOS and, more specifically, NO is expressed in the brains of SIV-infected monkeys and potentially contributes to SIV-induced CNS disease.
The increased levels of $\mathrm{NO}_{2}{ }^{-} / \mathrm{NO}_{3}{ }^{-}$in serial CSF samples from SIV-infected monkeys suggest that NO is produced locally within the CNS. A recent study has reported that no significant increase in average CSF levels of $\mathrm{NO}_{2}{ }^{-} / \mathrm{NO}_{3}{ }^{-}$were observed in HIV-infected patients (37). However, significant levels of $\mathrm{NO}_{2}{ }^{-} / \mathrm{NO}_{3}{ }^{-}$have been reported to be present in the CSF of patients with either bacterial or viral meningitis, suggesting that NO may play a role in the pathogenesis of this disease $(36,37)$. A sharp increase in $\mathrm{NO}_{2}{ }^{-} /$ $\mathrm{NO}_{3}{ }^{-}$levels in the CSF of monkey 185 was observed 7 days following infection. Whether this was in response to viral infection of the CNS is unclear, as only low levels of SIV p27 protein were present at this time. However, SIV is able to infect the CNS of rhesus monkeys very early following infection (45), thus the increased $\mathrm{NO}_{2}{ }^{-} / \mathrm{NO}_{3}{ }^{-}$levels may reflect a response to early viral infection of the brain. In support of this, Bukrinsky et al. (30) have shown that HIVinfected human macrophages produced peak amounts of NO between 5 and 7 days postinfection. The time frame of these observations somewhat parallel the kinetics of $\mathrm{NO}_{2}{ }^{-} / \mathrm{NO}_{3}{ }^{-}$production and would support early viral entry into the CNS.

We have demonstrated iNOS mRNA in the brains of monkeys infected with SIV by in situ hybridization. However, the identity of the cell type(s) responsible for iNOS expression in brain tissue from SIV-infected monkeys is not known. Monocyte/macrophage have been shown to be the primary cell type responsible for iNOS production in the brains of rats infected with borna disease virus and mice infected with LCMV $(43,44)$. Human fetal astrocytes can be stimulated for iNOS production following treatment with IFN $\gamma$ and IL-1 $\beta$ (40). In fact, astrocytes were thought to be responsible for production of iNOS in demyelinating lesions of MS patients (29). Thus, it is entirely possible that cells other than microglia are responsible for iNOS expression in the brain of SIV-infected monkeys.

The cytokines IFN $\gamma$ and IL-1 $\beta$, alone or in combination with other factors, have been shown to contribute to the stimulation of cultured human monocyte/macrophage and astrocytes to produce iNOS $(40,41)$. We have demonstrated expression of IFN $\gamma$ and IL- $1 \beta$ RNA in the brain of a monkey with SIV-induced CNS disease. It is interesting to speculate that SIV infection of the CNS results in the expression of IFN $\gamma$, IL- $1 \beta$, and other cytokines, which, in turn, activates resident and/or inflammatory cells to pro- 


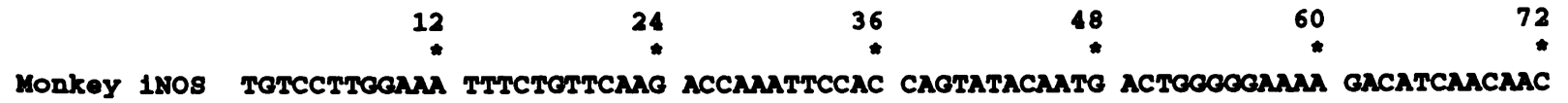
CysproTrplys PheLeuphelys ThrLysPheH1s GlnTyrThrMet ThrolyGlyLys AspIleAsnasn>

Human 1Nos

Ala Asn Glu

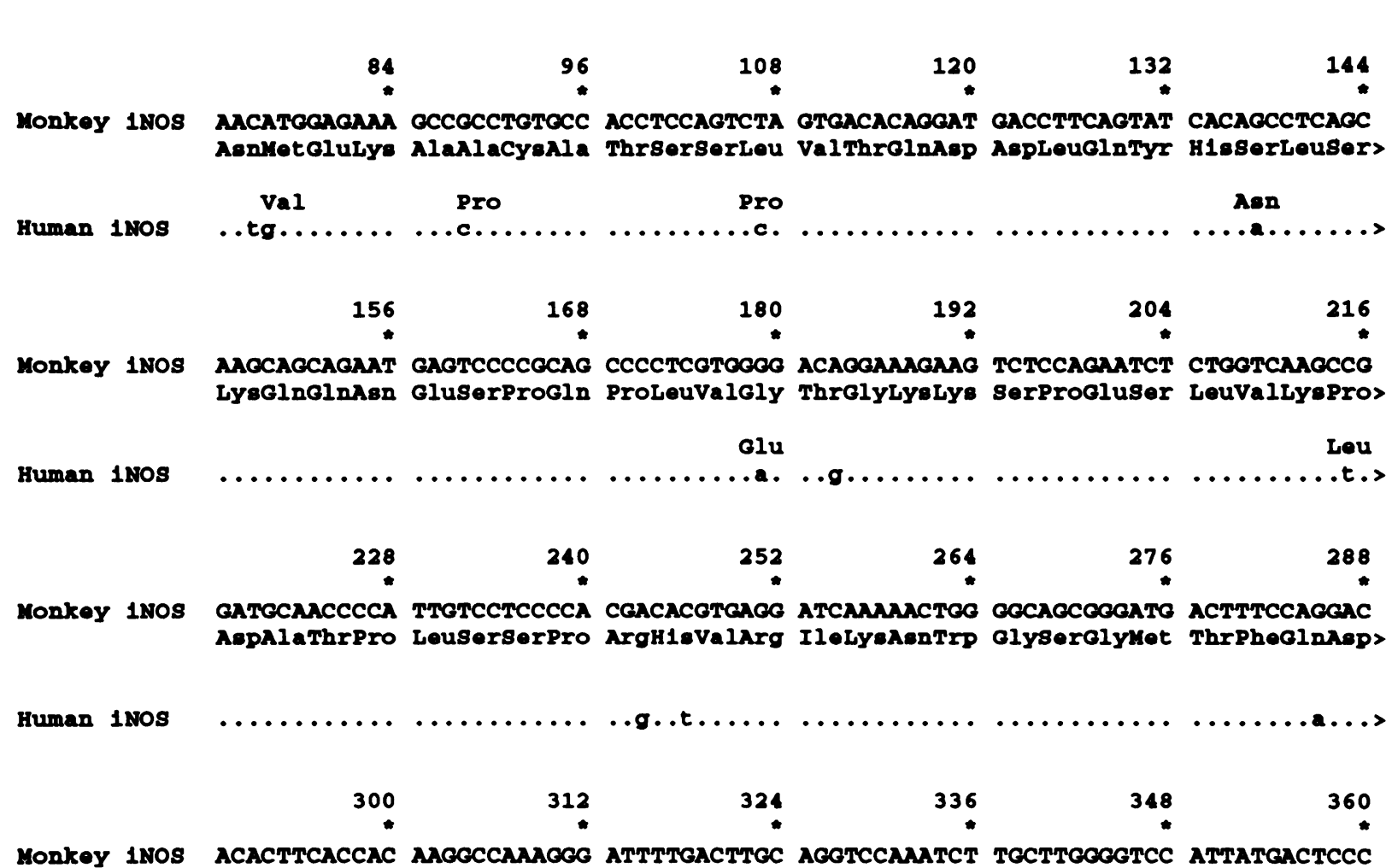

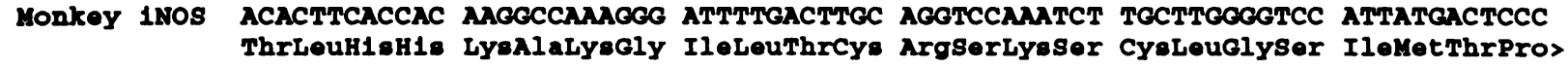

Human 1Nos

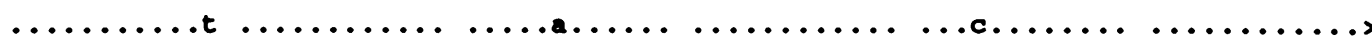

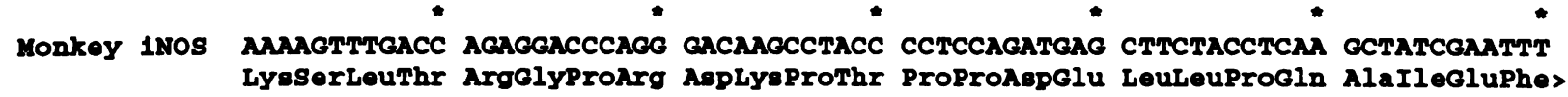

Human 1NOS

Human 1NOS

FIG. 4. Sequence of iNOS cDNA from LPS-stimulated microglia

The iNOS-specific PCR products were cloned and sequenced. The human hepatic iNOS sequence (39) was aligned to the monkey iNOS sequence. The monkey microglia iNOS was $\geq 95 \%$ identical to nucleotide and amino acid sequence of human hepatic iNOS. Amino acids are shown in three-letter code, dots indicate homology to human iNOS, while nucleotide differences are indicated by a letter, and amino acid differences are noted by the three-letter code. 
duce iNOS. The expression of iNOS would then be able to contribute to the development of neuropathology.

Mouse macrophage and microglia are capable of producing iNOS following exposure to various cytokines $(24,46)$. Considerable evidence now exists that human monocyte/macrophage can be stimulated to produce iNOS $(30,42)$. However, human microglia do not appear to be efficient in iNOS production following exposure to IFN $\gamma$ and LPS (47). HIV-1-infected human monocyte/macrophages have been shown to produce iNOS and NO following LPS and TNF $\alpha$ stimulation (30). Human hepatocytes, as well as human lung epithelial cells, require exposure to a combination of factors which include IFN $\gamma$, TNF $\alpha$, IL- $1 \beta$, and LPS in order to be stimulated to produce iNOS $(38,39)$. We have shown that microglia obtained from an SIV-infected monkey can be stimulated with LPS to produce iNOS, whereas unstimulated microglia do not express iNOS. The effects of other factors such as IFN $\gamma$, IL- $1 \beta$, or TNF $\alpha$ on microglial iNOS production have not been yet been examined, and this would be of great interest in light of our observations that IFN $\gamma$ and IL- $1 \beta$ are produced in the brain during SIV infection.

High levels of NO may alter normal cell function by inhibiting enzyme function, inducing apoptosis (26), or disrupting signals for neurotransmission (22). NO has also been shown to damage and kill cultured neurons (15). We have also determined that microglia from SIV-infected monkeys produce superoxide anion $\left(\mathrm{O}_{2}{ }^{-}\right)$(data not shown). NO reacts with $\mathrm{O}_{2}{ }^{-}$to form the peroxynitrite anion, which is relatively stable at physiological $\mathrm{pH}$, thus enabling this molecule to diffuse over a wide tissue area (27). Cellular targets for peroxynitrite include lipid peroxidation, which is directly toxic to cells and nitration of tyrosine residues which can disrupt signal transduction $(27,28)$. Thus, in addition to having a direct toxic effect on cells, NO may indirectly mediate a variety of other potentially neuropathogenic mechanisms.

In addition to inducing iNOS, IFN $\gamma$ may activate cells of the CNS to produce other neurotoxic factors including TNF $\alpha$, IL-2, and TGF $\beta$, prostaglandins, and arachidonic acid metabolites $(16,17)$. Expression of IFN $\gamma$ may also influence viral load in the brain of SIV-infected monkeys (48). Elevated levels of IL-1 $\beta$ have been observed in the brains of patients with HIV-1-induced CNS disease $(17,49)$. Increased levels of IL- $1 \beta$ have been shown to kill oligodendrocytes and destroy myelin (17). Furthermore, IL- $1 \beta$ has been shown to induce expression of other cytokines such as TNF $\alpha$ and IL-6, as well as enhance HIV-1 replication (17). Although the source of IFN $\gamma$ has not been investigated, we have previously identified the presence of $\mathrm{CD}^{+}$-cytotoxic $\mathrm{T}$ lymphocytes in the brains of SIV-infected monkeys with SIV-encephalitis (50). These cells represent a potential source of IFN $\gamma$.

The demonstration that iNOS and $\mathrm{NO}_{2}{ }^{-}$l $\mathrm{NO}_{3}{ }^{-}$are produced during the course of SIV infection of the CNS suggests that NO could potentially be contributing to SIV-induced CNS disease. However, NO is but one of many host factors produced that could lead to neurologic disease. Further work with the SIV/rhesus monkey model may provide valuable insight into identifying key events in the pathology leading to HIV-1-associated CNS disease and ADC.

\section{ACKNOWLEDGMENTS}

We thank Dr. Floyd Bloom for advice and support and Michelle Zandonatti for excellent technical assistance. This is Scripps Research Institute Manuscript Number 9451-NP. This work was supported by NIMH AIDS Center Grant MH 47680 and National Institutes of Health (NIH) Grant AR40981. TEL was supported (in part) by Postdoctoral Fellowship Grant FA 1163Al from the National Multiple Sclerosis Society and NIH Training Grant MH 19185.

\section{REFERENCES}

1. Gendelman HE, Lipton SA, Tardieu M, Bukrinsky MI, Nottet HSLM. (1994) The neuropathogenesis of HIV-1 infection. J. Leukoc. Biol. 56: 389-398.

2. Rao C, Anzil AP, Sher JH. (1993) The neuropathology of AIDS: A review. Adv. Neuroimm. 3: 1-15.

3. Sharer L. (1992) Pathology of HIV-1 infection of the central nervous system: A review. J. Neuropath. Exp. Neurol. 51: 3-11.

4. Desrosiers R. (1990) The simian immunodeficiency viruses. Annu. Rev. Immunol. 8: 557578.

5. Kestler H, Kodama T, Ringler D, et al. (1990) Induction of AIDS in rhesus monkeys by molecularly cloned simian immunodeficiency virus. Science 248: 1109-1112.

6. Hurtrel B, Chakrabarti L, Hurtrel M, Maire 
M, Dormont D, Montagnier L. (1991) Early SIV encephalopathy. J. Med. Primatol. 20: 159-166.

7. Sharer L, Baskin G, Cho E, Murphey-Corb M, Blumberg B, Epstein L. (1988) Comparison of simian immunodeficiency virus and human immunodeficiency virus encephalitides in the immature host. Ann. Neurol. 23: S108-S112.

8. Kindt T, Hirsch V, Johnson P, Sawasdikosol S. (1992) Animal models for acquired immunodeficiency syndrome. Adv. Immunol. 52: 425-473.

9. Brinkmann R, Schwinn A, Muller J, et al. (1993) In vitro and in vivo infection of Rhesus monkey microglial cells by simian immunodeficiency virus. Virology 195: 561-568.

10. Brinkmann R, Schwinn A, Narayan O, et al. (1992) Human immunodeficiency virus infection in microglia: Correlation between cells infected in the brain and cells cultured from infectious brain tissue. Ann. Neurol. 31: 361-365.

11. Hurtrel B, Chakrabarti L, Hurtrel M, Montagnier L. (1993) Target cells during early SIV encephalopathy. Res. Virol. 144: 41-46.

12. Lackner AA, Smith MO, Munn RJ, et al. (1991) Localization of simian immunodeficiency virus in the central nervous system of rhesus monkeys. Am. J. Pathol. 139: 609-619.

13. O'Brien WA. (1994) Genetic and biologic basis of HIV-1 neurotropism. In: Price RW, Perry SW (eds). HIV, AIDS and the Brain. Raven Press, New York pp. 47-69.

14. Benos D, Hahn B, Bubien J, et al. (1994) Envelope glycoprotein gp120 of human immunodeficiency virus type 1 alters ion transport in astrocytes: Implications for AIDS dementia complex. Proc. Natl. Acad. Sci. USA 91: 494-498.

15. Dawson V, Dawson T, Uhl G, Snyder S. (1993) Human immunodeficiency virus type 1 coat protein neurotoxicity mediated by nitric oxide in primary cortical cultures. Proc. Natl. Acad. Sci. USA 90: 3256-3259.

16. Genis P, Jett M, Bernton EW, et al. (1992) Cytokines and arachidonic metabolites produced during human immunodeficiency virus (HIV)-infected macrophage-astroglia interactions: Implications for the neuropathogenesis of HIV disease. J. Exp. Med. 176: 1703-1718.

17. Merrill J, Chen I. (1991) HIV-1, macrophages, glial cells, and cytokines in AIDS nervous system disease. FASEB J. 5: 2391-2397.
18. Poli G, Fauci A. (1992) The role of monocyte/macrophages and cytokines in the pathogenesis of HIV infection. Pathobiology 60: $246-251$.

19. Heyes $M$, Rubinow D, Lane C, Markey S. (1989) Cerebrospinal fluid quinolinic acid concentrations are increased in acquired immune deficiency syndrome. Ann. Neurol. 26: 275-277.

20. Heyes M, Saito K, Crowley J, et al. (1992) Quinolinic acid and kynurenine pathway metabolism in inflammatory and non-inflammatory neurological disease. Brain 115: 1249-1273.

21. Marletta MA, Yoon PS, Iyengar R, Leaf CD, Wishnok JS. (1988) Macrophage oxidation of L-arginine to nitrite and nitrate: Nitric oxide is an intermediate. Biochemistry 27: 8706-8711.

22. Nathan C, Xie Q. (1994) Nitric oxide synthases: Roles, tolls, and controls. Cell 78: 915-918.

23. Zhang J, Dawson VL, Dawson TM, Snyder SH. (1994) Nitric oxide activation of poly(ADP-ribose) synthetase in neurotoxicity. Science 263: 687-689.

24. Nathan CF, Hibbs JB. (1991) Role of nitric oxide synthase in macrophage antimicrobial activity. Curr. Opin. Immunol. 3: 65-70.

25. Lancaster JR, Hibbs JB. (1990) EPR demonstration of iron-nitrosyl complex formation by cytotoxic activated macrophages. Proc. Natl. Acad. Sci. USA 87: 1223-1227.

26. Sarih M, Souvannavong V, Adam A. (1993) Nitric oxide synthase induces macrophage death by apoptosis. Biochem. Biophys. Res. Commun. 191: 503-508.

27. Beckman JS. (1991) The double-edged role of nitric oxide in brain function and superoxidemediated injury. J. Dev. Physiol. 15: 53-59.

28. Beckman JS, Ye YZ, Anderson PG, et al. (1994) Extensive nitration of protein tyrosines in human atherosclerosis detected by immunohistochemistry. Biol. Chem. HoppeSeyler 375: 81-88.

29. Bo L, Dawson TM, Wesselingh $S$, et al. (1994) Induction of nitric oxide synthase in demyelinating regions of multiple sclerosis brains. Ann. Neurol. 36: 778-786.

30. Bukrinsky MI, Nottet HSLM, Schmidtmayerova H, et al. (1995) Regulation of nitric oxide synthase activity in human immunodeficiency virus type 1 (HIV-1)-infected monocytes: Implications for HIV-associated neurological disease. J. Exp. Med. 181: 735-745.

31. Morgan MJ, Kimes AS, London ED. (1991) 
Possible roles for nitric oxide in AIDS and associated pathology. Med. Hypoth. 38: 189193.

32. Watry DD, Lane TE, Streb M, Fox HS. (1995) Transfer of neuropathogenic SIV with naturally infected microglia, Am. J. Pathol. 146: 914-923.

33. Sambrook J. (1989) In: Fritsch EF, Maniatis T (eds). Molecular Cloning: A Laboratory Manual. 2nd Ed. Cold Spring Harbor Press: Cold Spring Harbor, NY pp. 7.3-7.25.

34. Griffin DE, McArthur JC, Cornblath DR. (1991) Neopterin and interferon-gamma in serum and cerebrospinal fluid of patients with HIV-associated neurologic disease. $\mathrm{Neu}$ rology 41: 69-74.

35. Grimaldi LME, Martino GV, Franciotta DM, et al. (1991) Elevated alpha-tumor necrosis factor levels in spinal fluid from HIV-1-infected patients with central nervous system involvement. Ann. Neurol. 29: 21-25.

36. Visser JJ, Scholten RJPM, Hoekman K. (1994) Nitric oxide synthesis in meningococcal meningitis. Ann. Intern. Med. 120: 345346.

37. Milstien S, Sakai N, Brew BJ, et al. (1994) Cerebrospinal fluid nitrite/nitrate levels in neurologic diseases. J. Neurochem. 63: 1178 1180.

38. Asano K, Chee CBE, Gaston B, et al. (1994) Constitutive and inducible nitric oxide synthase gene expression, regulation, and activity in human lung epithelial cells. Proc. Natl. Acad. Sci. USA 91: 10089-10093.

39. Geller D, Lowenstein C, Shapiro R, et al. (1993) Molecular cloning and expression of inducible nitric oxide synthase from human hepatocytes. Proc. Natl. Acad. Sci. USA 90: 3491-3495.

40. Lee SC, Dickson DW, Liu W, Brosnan CF. (1993) Induction of nitric oxide synthase activity in human astrocytes by interleukin-1 beta and interferon-gamma. J. Neuroimmunol. 46: 19-24.

41. Reiling N, Ulmer AJ, Duchrow M, Ernst M, Flad HD, Hauschildt S. (1994) Nitric oxide synthase: mRNA expression of different isoforms in human monocytes/macrophages. Eur. J. Immunol. 24: 1941-1944.

42. Pietraforte D, Tritarelli E, Testa U, Minetti M. (1994) gp120 HIV envelope glycoprotein increases the production of nitric oxide in human monocyte-derived macrophages. J. Leukoc. Biol. 55: 175-182.

43. Campbell IL, Samimi A, Chiang CS. (1994) Expression of the inducible nitric oxide synthase: Correlation with neuropathology and clinical features in mice with lymphocytic choriomeningitis. J. Immunol. 153: 3622-3629.

44. Zheng Y, Schafer $M$, Weihe E, et al. (1993) Severity of neurological signs and degree of inflammatory lesions in the brains of rats with borna disease correlate with the induction of nitric oxide synthase. J. Virol. 67: 5786-5791.

45. Chakrabarti L, Hurtrel M, Maire M-A, et al. (1991) Early viral replication in the brain of SIV-infected Rhesus monkeys. Am. J. Pathol. 139: 1273-1280.

46. Merrill JE, Ignarro LJ, Sherman MP, Melinek J, Lane TE. (1993) Microglial cell cytotoxicity of oligodendrocytes is mediated through nitric oxide. J. Immunol. 151: 2132-2141.

47. Peterson PK, Hu S, Anderson WR, Chao CC. (1994) Nitric oxide production and neurotoxicity mediated by activated microglia from human versus mouse brain. J. Infect. Dis. 170: $457-460$.

48. Lairmore MD, Post AA, Goldsmith CS, Folks TM. (1991) Cytokine enhancement of simian immunodeficiency virus (SIV/mac) from a chronically infected cloned $\mathrm{T}$-cell line (HuT-78). Arch. Virol. 121: 43-53.

49. Tyor W, Glass J, Griffin J, et al. (1992) Cytokine expression in the brain during the acquired immunodeficiency syndrome. Ann. Neurol. 31: 349-360.

50. von Herrath $M$, Oldstone MBA, Fox HS. (1995) Simian immunodeficiency virus (SIV)-specific CTL in cerebrospinal fluid and brains of SIV-infected rhesus macaques. $J$. Immunol. 154: 5582-5589. 